\title{
Some recent Observations on the Biology of Roridula.
}

\author{
BY \\ R. MARLOTH, Ph.D., M.A. \\ With a Figure in the Text.
}

\begin{abstract}
MONG the various plants which possess a special interest A to the biologist there are hardly any of greater importance than the insectivorous plants. Belonging to several widely different natural orders, they are spread over all five continents, occurring in the forests of the tropics as well as in the tundra of the arctic regions, in the marshes near the shore of the sea as well as on the cloud-capped summits of the mountains.

South Africa possesses two genera of insectivorous plants, both belonging to the natural order Droseraceae, viz. Drosera and Roridula. While the European species of sundews are tiny plants with radical leaves and inconspicuous little white flowers, some of the South African species develop stalks nearly a foot high and bear large handsomely coloured flowers.

Unique in its structure, however, is the other genus, viz. Roridula, for while all other Droseraceae are small herbs only, Roridula forms shrubs. There are two species only in existence, no other shrubby Droseraceous plant being known. These two species are $R$. dentata, L. and $R$. Gorgonias Pl., which differ in their leaves as well as in the size of the plants,

[Annals of Botany, Vo1. XVII. No. LXV. January, 1903.]
\end{abstract}


for while the latter is a shrublet from I $_{2}$ to ${ }_{5} 5$ inches high, which possesses entire leaves, the former grows to a height of 4 feet and bears dentate leaves. The leaves of both species are closely covered with glandular hairs, similar in structure to those of Drosera (Fig. I5, I and 5). That the secretion

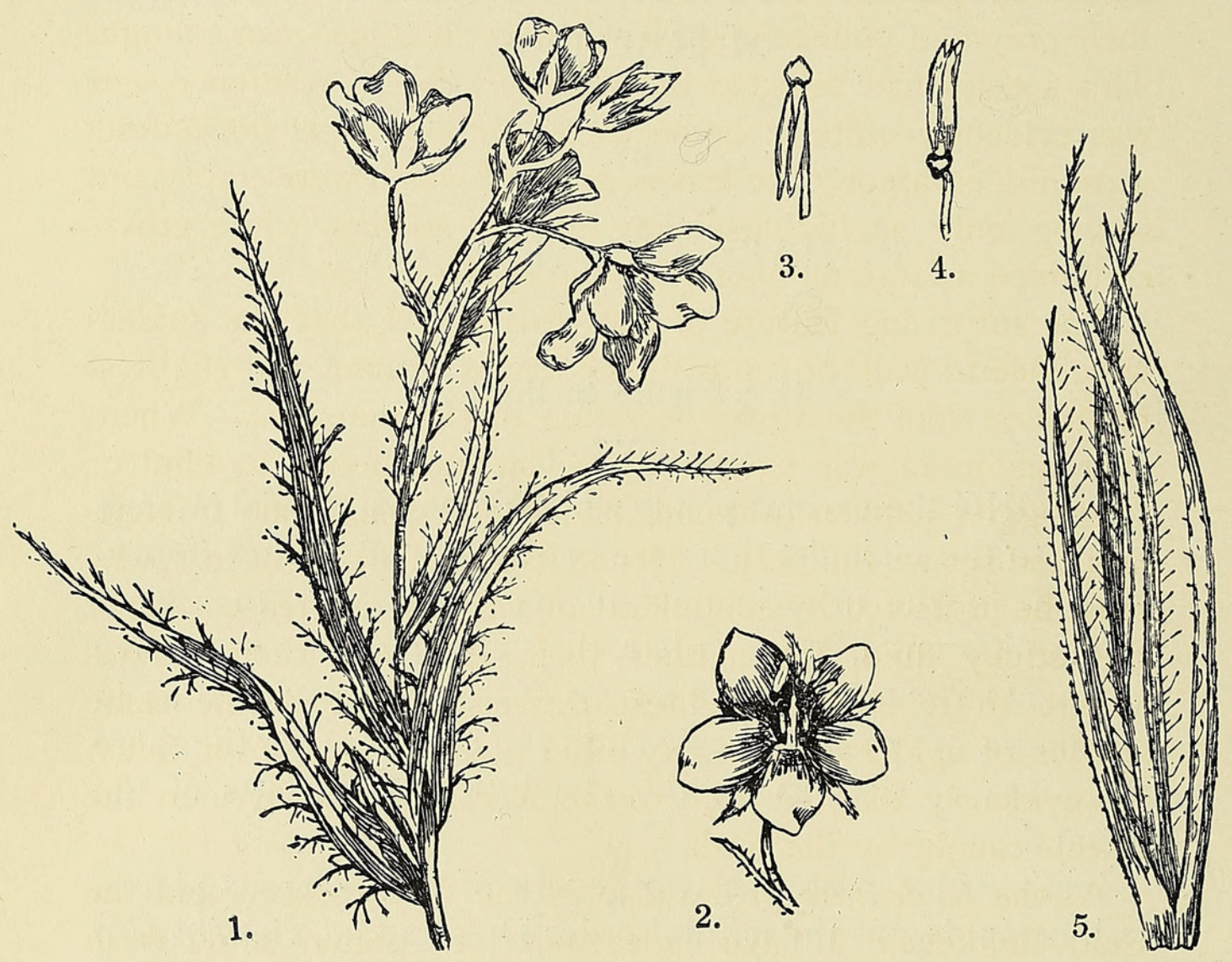

FIG. I5. I. Flowering branch of Roridula dentata, L. 2. Flower. 3. Stamen in its first stage. 4. Stamen in its second stage. 5. End of a twig of $R$. Gorgonias, Pl. All natural size.

of these hairs is most effective is proved by the large number of insects which are found on every shrub of the plant. This property of the plant is well known among the people of the districts where it grows, for sometimes they suspend branches of the shrub in their houses for the purpose of catching flies. In fact it is known to the country people as the fly-bush.

When recently visiting one of the localities where $R$. dentata is known to grow, viz. the valley above the Tulbagh water- 
fall, I noticed a spider walking about on the bushes, and on examining the bushes more closely I found that the spiders were quite numerous. They were all of one kind, belonging to the genus Synaema ${ }^{1}$ (Crab-spiders). Dr. Purcell, who kindly examined the specimens, is of the opinion that it is an undescribed species. The crab-spiders spin no web, but wait for their prey and pounce upon it whenever it comes near enough. This species had selected the Roridula for its residence, and was evidently quite at home there, for numerous little nests were hidden among the leaves, some of which were empty and serving only as hiding-places for the spiders, while others contained a large number of young spiders.

The surprising feature of the matter was, that the spiders were able to walk or run over the leaves without the slightest hindrance from the sticky secretion of the tentacles. Whenever an insect was caught by a leaf and began to hum or to struggle, a spider in its neighbourhood would dart from its nest and secure the prey. Hence it is evident that the spider must be protected by some kind of varnish or grease against the sticky fluid, for neither their legs nor their bodies adhere to it in the slightest degree. Whether the same species of spider lives on any other plant is not known, but it has evidently adapted itself to the Roridula, and lives on the insects caught by the bush.

As the $R$. dentata grows also in the Cedarbergen and the Cold Bokkeveld I have endeavoured to obtain some fresh material from those regions, in order to ascertain whether the spider occurs there as well, but owing to the disturbed state of the country I have not been successful as yet.

The other species of Roridula, viz. R. Gorgonias, was for a long time only known to occur on the mountains of the river Zonder Ende, but recently Dr. Stoneman had found it in the valley of the Steenbrass river. When I visited this locality last February, I found the greater part of the valley burnt out, but finally succeeded in discovering a small patch of the plant. There were no spiders or spiders' nests on them,

1 Nature, vol. lviii, I 898, p. 275. 
and whether such may occur at the other locality of the plant I am unable to say.

While studying the structure of the flowers of the shrub (Fig. I 5, 2), I noticed that the position of the anthers varied, for some anthers were appressed to the filament, i.e. they pointed downwards, while others formed the continuation of the filament, standing upright. I soon detected the cause of this difference of position, for, on irritating the connective of a stamen, I saw the anther swinging round with a jerk ejecting a little cloud of pollen. This showed that the stamens of Roridula are irritable (Fig. I5, 3 and 4).

This special contrivance showed that the fertilization of these flowers must be effected by insects; but in spite of my watching the shrubs for about an hour, I did not observe any visitor. The difficulty of the case was to understand how an insect could be adapted to visiting these flowers, for how could it escape being caught by the leaves or calyx-lobes, unless it had learnt to avoid the danger in some special way.

At last I found the solution of the problem, for I noticed a small hemipterous insect walking about between the leaves. I succeeded in securing a few of these insects, which were evidently as proof against the sticky fluid as the spiders. They, were kindly identified by Dr. Purcell and Mr. Mally as a species of Capsids, apparently undescribed. The microscope showed me that these insects possess a proboscis somewhat similar to that of a mosquito, and that they consequently obtain their food by perforating the tissues of plants and sucking their juices. As I found young specimens of this hemipter two months afterwards on plants of Roridula which I had brought with me to Capetown, and which I was cultivating in my garden, it is evident that the eggs had been deposited on the plants and that this insect lived on the juice of the young tissues of the Roridula. The question suggested itself, whether the flowers possessed any special attraction for this insect. On investigating the contents of the gland-like connectives of the stamens, I ascertained by micro-chemical reactions that the internal tissue of the connective contained 
sugar in its cells, while the cells of its epidermis were free from it. The connective is consequently not a nectary in the ordinary sense of the word; that means to say, it does not secrete honey on its surface, but it offers it only to insects which obtain their food by piercing the tissues. As our Capsid is not only able to do that but also to walk about freely on the plant, as if there were no tentacles-with sticky glands, it is obvious that this insect is specially adapted to the fertilization of the flowers of Roridula.

In order to obtain, if possible, some evidence in favour of this view, I examined the few specimens of the insect which I possessed for pollen-grains. Two specimens which I examined did not contain any, but the third one carried quite a number of grains of Roridula pollen between the hairs of its body.

Taking all these facts into consideration, there can be no doubt with regard to the relation between this insect and the plant.

As stated above, there were no spiders on the specimens of the other species which I found in the Steenbrass river valley, but I noticed at once that $R$. Gorgonias was also inhabited by a Capsid, which was evidently quite different from that on $R$. dentata. As on that occasion I had provided myself with a muslin bag I was able to secure a larger number of the insects. On examining the spirits of wine in which I had preserved them, I found numerous pollen grains of Roridula, and as the structure of the stamens of this plant, especially that of its connectives, is quite similar to that of $R$. dentata, it is evident that this insect lives on $R$. Gorgonias in the same way as the other one on $R$. dentata.

Summing up these observations, we find that the Roridula catches insects in order to obtain an additional food-supply, but that a spider robs the plant of a share of its prey in spite of the sticky tentacles.

At the same time the Capsid takes some of the juice of the plant, having likewise acquired immunity from the dangers of the glandular hairs, but the plant utilizes this otherwise 
unwelcome lodger by offering him some special tit-bits in its flowers, securing in this way, with the aid of some specially developed contrivances, the cross-fertilization of its flowers. It is hardly possible to imagine a more complicated relationship of plants and animals.

There is another peculiarity of $R$. dentata which deserves special attention. All other Droseraceous plants occur in swampy or wet places, and the annuals are found in localities which are moist during certain seasons of the year. The locality, however, where I found $R$. dentata was the dry slope of a hill, which consisted of hard iron gravel and clay. No other hydrophilous plants were to be seen. The unusual nature of the locality induced me to dig up several plants and to take a sample of the soil from the lowest layer into which its roots had penetrated. I put the sample at once into a wellcorked tube and analysed it later on. It contained only I. 74 per cent. of moisture (expelled at $120^{\circ} \mathrm{C}$.), and the loss by ignition, which represents the combustible matter and the chemically bound water, amounted only to 3 . I per cent. As the young plants as well as the larger shrubs possess a comparatively small root-system, and as the amount of moisture in the soil is hardly sufficient for strictly xerophilous plants, it is surprising that a shrub which belongs to a typically hygrophilous order should be able to exist in such a locality.

The locality in which I found $R$. Gorgonias, however, was of the usual nature, consisting of moist sandy soil, on which, among other plants, a species of Drosera, viz. D. cuneifolia, grew.

Dr. Purcell has drawn my attention to an article by R. I. Pocock, published in 1898 in Nature ${ }^{1}$, from notes supplied by Mr. A. Everett.

This gentlemen has observed that a species of Nepenthes in North Borneo is often inhabited by another crab-spider, viz. Misumena nepenthicola. This spider plunges boldly into the fluid of the pitchers whenever threatened by danger, and it is

1 Nature, vol. lviii, I 898 , p. 275. 
assumed that it preys upon the insects which enter the pitcher or which are caught in its fluid.

Mr. Mally, of the Cape Entomological Department, has kindly made a general list of the insects found on a handful

- of branches of Roridula dentata, gathered by me on the occasion of my visit to the Tulbagh mountains. This list shows :-

Hymenoptera : twenty-five specimens belonging to the subfamilies Sphecina and Apina.

Diptera: twenty specimens of Muscidae.

Coleoptera: Of Coccinellidae were present Chilomenes lunatus, Fab., Exochomus nigromaculatus, Goeze, Pharus sexguttatus, Gyllh. and two other species.

Of Scarabaeidae two species were present, viz. Lepitrix stigma, de Geer, and Pritrichia capicola, Fab.

Hemiptera: One specimen each of Lygaeidae, Reduviidae and Membracidae.

CAPETOWN.

May, 1902. 


\section{$2 \mathrm{BHL}$ Biodiversity Heritage Library}

Marloth, R. 1903. "Some recent observations on the biology of Roridula." Annals of botany 17, 151-157.

https://doi.org/10.1093/oxfordjournals.aob.a088908.

View This Item Online: https://www.biodiversitylibrary.org/item/235015

DOI: https://doi.org/10.1093/oxfordjournals.aob.a088908

Permalink: https://www.biodiversitylibrary.org/partpdf/318707

\section{Holding Institution}

Smithsonian Libraries

\section{Sponsored by}

Biodiversity Heritage Library

\section{Copyright \& Reuse}

Copyright Status: Not in copyright. The BHL knows of no copyright restrictions on this item.

This document was created from content at the Biodiversity Heritage Library, the world's largest open access digital library for biodiversity literature and archives. Visit BHL at https://www.biodiversitylibrary.org. 